\title{
Hubungan Lingkungan Fisik dan Tindakan Penduduk dengan Kejadian ISPA pada Balita di Wilayah Kerja Puskesmas Lubuk Buaya
}

Irma Suryani ${ }^{1}$, Edison $^{2}$, Julizar Nazar ${ }^{3}$

\begin{abstract}
Abstrak
Angka kematian akibat infeksi saluran pernapasan akut (ISPA) di negara berkembang sebanyak 20\% dimana 1/3 - 1/2 merupakan kematian pada balita. Penelitian ini bertujuan untuk mengetahui hubungan lingkungan fisik berupa ventilasi, pencahayaan alami, kelembaban rumah, kepadatan hunian rumah dan tindakan penduduk yang meliputi kebiasaan merokok dalam rumah, kebiasaan buka jendela dan penggunaan bahan bakar rumah tangga dengan kejadian ISPA pada balita. Penelitian ini merupakan studi analitik dengan desain cross sectional, yang dilakukan di wilayah kerja Puskesmas Lubuk Buaya Padang pada bulan Desember 2013 dengan jumlah sampel 106 ibu yang mempunyai balita. Sampel diambil secara simple random sampling. Pengumpulan data dari responden dilakukan menggunakan kuesioner dan lembaran observasi. Analisis data menggunakan uji chi square dengan $p<0.05$ dan $0.0<\mathrm{C} c<1.00$. Hasil penelitian menunjukkan ada hubungan yang lemah antara ventilasi $(\mathrm{p}=0.000, \mathrm{Cc}=0.359)$, pencahayaan alami $(p=0.001, C c=0.311)$, kepadatan hunian $(p=0.000, C c=0.381)$, kebiasaan merokok di dalam rumah $(p=0.002, C c=0.302)$, kebiasaan buka jendela $(p=0.001, C c=0.333)$ dan penggunaan bahan bakar rumah tangga $(p=0.027, C c=0.210)$ dengan kejadian ISPA pada balita, sedangkan kelembaban rumah tidak ada hubungan dengan kejadian ISPA pada balita.
\end{abstract}

Kata kunci: ISPA balita, lingkungan fisik, tindakan penduduk

\begin{abstract}
The mortality rate due to Acute Respiratory Infections (ARI) in developing countries is about $20 \%$ which is $1 / 3-1 / 2$ is the death of the children under five years old. The objective of this research was to determined the correlation between the physical environment which include the ventilation, the natural lighting, the house humidity, the density of residential house, and community behavior which include the habitual of smoking at house, the habitual of window open and household fuel use with the incidence of ARI on children under five years old. This research is an analytical study with cross sectional design, which done in work area of Lubuk Buaya community health centers Padang on December 2013 with 106 mothers with children under five years as the sample. Samples are taken by simple random sampling. The collection of data from respondents was conducted using questionnaires and observation sheets. Data analysis using chi square test with $p<0.05$ and $0.0<C c<1.00$ The result showed that there was a weak correlation between ventilation ( $p=0.000, C c=0.359)$, natural lighting ( $p=0.00, C c=0.311)$, the density of residential house $(p=0.000, C c=0.381)$, the habitual of smoking at house $(p=0.002, C c=0.302)$, the habitual of window open ( $p=0.001, C c=0.333$ ) and household fuels use $(p=0.027, C c=0.210)$ with the incidence of $A R I$ in children under five yers old and no correlation between the house humidity with ARI in children under five years old.
\end{abstract}

Keywords: $A R I$ in children under five years old, physical environment, community behavior 
Affiliasi penulis : 1 . Pendidikan Dokter FK UNAND (Fakultas Kedokteran Universitas Andalas Padang), 2. Bagian IKM FK UNAND, 3. Bagian Fisika FK UNAND

Korespondensi : Irma Suryani, E-mail: irmasuryani.ima@gmail.com, Telp: 085263040010

\section{PENDAHULUAN}

Infeksi Saluran Pernapasan Akut (ISPA) merupakan salah satu masalah kesehatan yang ada di negara maju dan berkembang. ${ }^{1}$ Hal ini karena tingginya angka kesakitan dan kematian akibat ISPA pada balita. Menurut laporan WHO, angka kesakitan akibat infeksi saluran pernapasan akut mencapai $8,2 \% .^{2}$ Kunjungan kesehatan akibat infeksi saluran pernapasan akut dilaporkan sebanyak $20 \%$ di negara berkembang. Di Indonesia, infeksi saluran pernapasan akut menempati urutan pertama pada tahun 2008, 2009 dan 2010 dari 10 penyakit terbanyak pada pasien rawat jalan di Indonesia. ${ }^{3}$

Infeksi saluran pernapasan akut merupakan kasus yang tinggi pada balita dan anak. Penyakit yang diderita oleh anak dibawah 5 tahun, lima puluh persen diantaranya adalah infeksi saluran pernapasan akut. Pada anak-anak berusia 5 - 12 tahun, kurang lebih sebanyak 30\% anak menderita penyakit ini. Pada umumnya infeksi saluran pernafasan akut ini mengenai saluran pernapasan atas dan saluran pernapasan bawah terutama pneumonia. ${ }^{4}$ Angka kematian akibat infeksi saluran pernapasan akut di negara berkembang sebanyak $20 \%$ dimana $1 / 3-1 / 2$ merupakan kematian pada balita. ${ }^{4}$

Pneumonia adalah pembunuh utama balita di dunia, lebih banyak dibandingkan dengan gabungan penyakit AIDS, malaria dan campak. Di negara berkembang, satu balita meninggal dalam 20 detik karena pneumonia dari 9 juta total kematian balita. Dari 5 kematian balita, 1 di antaranya disebabkan oleh pneumonia. Di negara berkembang 60\% kasus pneumonia disebabkan oleh bakteri. Menurut hasil Riskesdas 2007 proporsi kematian balita karena pneumonia menempati urutan kedua $(13,2 \%)$ setelah diare. $^{5}$

Dalam perjalanannya, penyakit infeksi saluran pernapasan akut dipengaruhi oleh berbagai macam faktor risiko. Secara umum terdapat tiga faktor risiko terjadinya ISPA, yaitu faktor lingkungan, faktor individu anak serta faktor perilaku. Faktor lingkungan meliputi: pencemaran udara dalam rumah (asap rokok dan asap hasil pembakaran bahan bakar untuk memasak dengan konsentrasi yang tinggi), ventilasi rumah dan kepadatan hunian. Faktor individu anak meliputi: umur anak, berat badan lahir, status gizi, vitamin A dan status imunisasi. Faktor perilaku meliputi perilaku pencegahan dan penanggulangan ISPA pada bayi atau peran aktif keluarga/masyarakat dalam menangani penyakit ISPA. ${ }^{6}$ Depkes menyebutkan bahwa faktor penyebab ISPA pada balita adalah berat badan bayi rendah (BBLR), status gizi buruk, imunisasi yang tidak lengkap, kepadatan tempat tinggal dan lingkungan fisik. ${ }^{7}$ Asap rumah tangga yang masih menggunakan kayu bakar juga menjadi salah satu faktor risiko pneumonia. Hal ini dapat diperburuk apabila ventilasi rumah kurang baik dan dapur menyatu dengan ruang keluarga atau kamar. ${ }^{1}$ Rumah yang ventilasinya tidak memenuhi syarat kesehatan akan mempengaruhi kesehatan penghuni rumah menurut pendapat Notoatmodjo. ${ }^{8}$

Pada penyakit ISPA ada yang disebut dengan ISPA akibat polusi. ISPA akibat polusi adalah ISPA yang disebabkan oleh faktor risiko polusi udara seperti asap rokok, asap pembakaran di rumah tangga, gas buang sarana transportasi dan industri, kebakaran hutan dan lain lain. ${ }^{9}$ Dampak rokok tidak hanya mengancam siperokok tetapi juga orang disekitarnya atau perokok pasif. Berdasarkan laporan Badan Lingkungan Hidup Amerika (EPA /Environmental Protection Agency) mencatat tidak kurang dari 300.000 anak berusia 1-5 tahun menderita bronkhitis dan pneumonia karena turut menghisap asap rokok yang dihembuskan orang disekitarnya terutama ayah dan ibunya. ${ }^{10}$ Populasi yang sangat rentan terhadap asap rokok adalah anak-anak karena mereka menghirup udara lebih sering dari pada orang dewasa. Organ anak-anak masih lemah sehingga rentan terhadap gangguan dan masalah sehingga jika terkena dampak buruk maka perkembangan organnya tidak sesuai dengan semestinya. ${ }^{11}$

Nindya dan Sulystiorini pada tahun 2005 melakukan penelitian dengan membandingkan hubungan sanitasi fisik rumah dengan kejadian ISPA di tiga wilayah yakni Penjaringan Sari Rungkut Surabaya, Desa Sidomulyo Sidoarjo dan Desa Tual Maluku Tenggara didapatkan hasil bahwa ventilasi 
adalah sanitasi rumah yang sangat mempengaruhi ISPA. $^{12}$ Penelitian Oktaviani menunjukan ada hubungan antara ventilasi, pencahayaan alami, kelembaban, jenis lantai, dinding dan atap rumah terhadap kejadian ISPA pada balita di desa Cepogo Kabupaten Boyolali. ${ }^{13}$ Dan penelitian oleh Oktaviani dkk di kota Prabumulih, Sumatera Selatan menunjukan adanya hubungan perilaku penduduk berupa pengetahuan keluarga terhadap ISPA berpengaruh terhadap kejadian ISPA. ${ }^{14}$ Darwel pada tahun 2007 telah melakukan penelitian di Air Dingin kota Padang dan didapatkan ada hubungan antara ventilasi kamar, kepadatan huni, kebiasaan merokok dan penggunaan obat nyamuk bakar dengan kejadian ISPA. $^{15}$

Menurut data Dinas Kesehatan Kota Padang pada tahun 2012, infeksi saluran pernapasan akut termasuk dalam sepuluh penyakit terbanyak di kota Padang. Dinas Kesehatan Kota Padang mencatat terdapat 63.481 kasus infeksi saluran pernapasan akut di seluruh puskesmas pada tahun $2012 .^{16}$

Dari studi awal, peneliti melakukan pengamatan pada 30 rumah penduduk penderita ISPA dan didapatkan hasil 33,3\% rumah dengan ventilasi tidak memenuhi syarat dan 60\% rumah dengan pencahayaan alami tidak memenuhi syarat.

Tujuan penelitian ini adalah untuk mengetahui hubungan lingkungan fisik berupa ventilasi, pencahayaan alami, kelembaban rumah dan kepadatan hunian rumah serta tindakan penduduk berupa kebiasaan merokok, kebiasaan buka jendela dan penggunaan bahan bakar rumah tangga dengan kejadian ISPA pada balita di wilayah kerja Puskesmas Lubuk Buaya Koto Tangah kota Padang.

\section{METODE}

Jenis penelitian adalah studi analitik dengan desain cross sectional. Populasi penelitian adalah seluruh ibu yang mempunyai anak balita di wilayah kerja Puskesmas Lubuk Buaya kota Pdang dengan sampel berjumlah 106 ibu yang diambil secara simple random sampling pada 6 kelurahan di wilayah kerja Puskesmas Lubuk Buaya yakni kelurahan Lubuk Buaya, kelurahan Bungo Pasang, kelurahan Pasia Nan Tigo, kelurahan Ganting Batang Kabung, kelurahan Parupuk Tabing dan kelurahan Dadok Tunggul Hitam.

Kriteria inklusi adalah ibu yang mempunyai balita usia 1 - 59 bulan sebelum tanggal 31 Desember 2013, ibu dan balitanya tinggal di wilayah kerja Puskesmas Lubuk Buaya pada saat dilakukan penelitian, rumah sedang tidak mengalami renovasi / perbaikan bangunan baik jendela, dinding maupun langit-langit atau atap rumah dan bersedia menjadi responden serta dapat berkomunikasi dengan baik. Kriteria ekslusi adalah ibu dan balitanya merupakan pendatang baru di wilayah kerja Puskesmas Lubuk Buaya terhitung 2 minggu sebelum didiagnosis ISPA.

Variabel dependen penelitian adalah ISPA pada balita. Cara ukur dari ISPA pada balita menggunakan wawancara dengan kuesioner. Hasil ukurnya yaitu menderita ISPA apabila memenuhi $>3$ gejala ISPA dan tidak menderita ISPA apabila $<3$ gejala ISPA.

Variabel independen terdiri dari ventilasi, pencahayaan alami, kelembaban rumah, kepadatan hunian rumah, kebiasaan merokok, kebiasaan buka jendela dan penggunaan bahan bakar rumah tangga. Ventilasi adalah saluran udara untuk proses pergantian udara segar ke dalam dan mengeluarkan udara kotor dari suatu ruangan tertutup. Data didapatkan dengan cara observasi dan pengukuran menggunakan meteran dengan hasil memenuhi syarat jika $\geq 10 \%$ luas lantai rumah dan tidak memenuhi syarat jika $<10 \%$ luas lantai. Pencahayaan alami adalah penerangan rumah secara alami oleh sinar matahari melalui jendela, lubang angin dan pintu dari arah timur di pagi hari dan barat disore hari. Data didapatkan dengan cara observasi dan pengukuran menggunakan meteran dengan hasil memenuhi syarat jika $\geq 15 \%$ dari luas lantai dan tidak memenuhi syarat jika $<15 \%$ dari luas lantai. Kelembaban udara adalah kandungan uap air yang dapat dipengaruhi oleh sirkulasi udara dalam rumah dan pencahayaan alami rumah. Data didapatkan dengan cara pengukuran menggunakan hygrometer dengan hasil ukur baik jika $40 \%-70 \%$ dan tidak baik jika $<40 \%$ atau $>70 \%$. Kepadatan hunian rumah adalah perbandingan luas bangunan yang tersedia dibagi dengan jumlah penghuni rumah. Data didapatkan dengan cara obser- 
vasi dan pengukuran menggunakan meteran dengan hasil ukur padat jika satu orang menempati $<8 \mathrm{~m}^{2}$ dan tidak padat jika satu orang menempati $\geq 8 \mathrm{~m}^{2}$. Kebiasaan merokok adalah perilaku anggota keluarga yang merokok didalam rumah. Data didapatkan dengan cara wawancara menggunkan kuesioner dengan hasil ukur merokok didalam rumah dan tidak merokok didalam rumah. Bahan bakar rumah tangga adalah bahan yang digunakan untuk memasak. Data didapatkan dengan cara wawancara menggunakan kuesioner dengan hasil ukur tradisional jika bahan bakar berupa arang atau kayu dan modern jika bahan bakar berupa kompor minyak, kompor gas atau kompor listrik. Dan terakhir adalah kebiasaan membuka jendela rumah, yaitu kebiasaan penghuni rumah untuk membuka jendela yang ada dirumah. Data didapatkan dengan cara wawancara menggunakan kuesioner dengan hasil ukur baik jika selalu dibuka setiap hari dan tidak baik jika kadang - kadang dibuka dan tidak pernah dibuka.

Langkah-langkah pengolahan data yang dilakukan yaitu memeriksa kelengkapan data dari kuesioner, memberikan kode disetiap data variabel yang telah terkumpul, memasukkan data ke dalam komputer dan memeriksa kembali data yang telah dimasukkan dan memastikan bahwa data tersebut telah bersih dari kesalahan.

Analisis data terdiri dari analisi univariat dan bivariat. Analisis bivariat digunakan untuk mengetahui hubungan antara dua variabel yaitu ventilasi dengan kejadian ISPA pada balita, pencahayaan alami dengan kejadian ISPA pada balita, kelembaban rumah dengan kejadian ISPA pada balita, Kepadatan hunian rumah dengan kejadian ISPA pada balita, kebiasaan merokok dalam rumah dengan kejadian ISPA pada balita, kebiasaan buka jendela rumah dengan kejadian ISPA pada balita dan penggunaan bahan bakar rumah tangga (tradisional dan modern) dengan kejadian ISPA pada balita menggunakan uji chi square dengan derajat kemaknaan $\mathrm{p}<0.05$ dan Coefficient contingency $0.2<\mathrm{Cc}<1.0$.

\section{HASIL}

\section{Karakteristik balita}

Dari 106 sampel didapatkan balita paling kecil berumur 2 bulan dan paling besar berumur 54 bulan dengan balita yang paling banyak muncul adalah balita berusia 24 bulan. Jenis kelamin perempuan paling banyak ditemukan yakni sebanyak 56 orang $(52.83 \%)$ dan jenis kelamin laki-laki sebanyak 50 orang $(47.17 \%)$

\section{Analisis Univariat}

\section{Lingkungan Fisik}

Tabel 1. Ventilasi, Pencahayaan Alami, Kelembaban Rumah dan Kepadatan Hunian Rumah di Wilayah Kerja Puskesmas Lubuk Buaya

\begin{tabular}{lcc}
\hline \multicolumn{1}{c}{ Variabel } & Jumlah & $\%$ \\
\hline Ventilasi & 47 & 44,34 \\
Memenuhi syarat & 59 & 55.66 \\
Tidak memenuhi syarat & & \\
\hline Pencahayaan Alami & 26 & 24,53 \\
Memenuhi syarat & 80 & 75,47 \\
Tidak memenuhi syarat & & \\
\hline Kelembaban & 78 & 73,58 \\
$40 \%-70 \%$ & 28 & 26,42 \\
<40\% dan > 70\% & & \\
\hline Kepadatan Hunian & 58 & 54,72 \\
Padat & 48 & 45,28 \\
\hline Tidak Padat &
\end{tabular}

\section{Tindakan Penduduk}

Tabel 2. Kebiasaan Merokok, Kebiasaan Membuka Jendela dan Penggunaan Bahan Bakar Rumah Tangga Responden di Wilayah Kerja Puskesmas Lubuk Buaya Kota Padang 2013

\begin{tabular}{lcc}
\hline \multicolumn{1}{c}{ Variabel } & Jumlah & $\%$ \\
\hline Kebiasaan Merokok & 66 & 62,66 \\
Merokok & 40 & 37,74 \\
Tidak merokok & & \\
\hline Kebiasaan Buka Jendela & 70 & 68,87 \\
Ya & 36 & 31,13 \\
Tidak & & \\
\hline Penggunaan Bahan Bakar & 15 & 14,15 \\
Tradisional & 91 & 85,85 \\
Modern &
\end{tabular}

\section{Analisis Bivariat}

1. Hubungan Ventilasi Rumah dengan Kejadian ISPA Berdasarkan tabel 3 dapat diketahui bahwa persentase balita yang mengalami ISPA lebih tinggi pada rumah yang ventilasinya tidak memenuhi syarat (84.7\%) dibandingkan dengan yang memenuhi syarat (48.9\%). Hasil uji chi square didapatkan nilai $p$ 
sebesar $0.000 \quad(p<0.05)$, yang berarti terdapat perbedaan kejadian ISPA pada balita berdasarkan ventilasi rumah yang memenuhi syarat dan tidak memenuhi syarat di wilayah kerja Puskesmas Lubuk Buaya Kota Padang. Berdasarkan nilai Coefficient of contingency (Cc) terdapat hubungan yang lemah antara kejadian ISPA dengan ventilasi rumah pada balita di wilayah kerja Puskesmas Lubuk Buaya kota Padang dengan nilai $\mathrm{Cc}=0.359$.

Tabel 3. Hubungan Ventilasi Rumah dengan Kejadian ISPA Pada Balita di Wilayah Kerja Puskesmas Lubuk Buaya Kota Padang Tahun 2013

\begin{tabular}{|c|c|c|c|c|c|c|c|c|}
\hline \multirow{3}{*}{ Ventilasi } & \multicolumn{4}{|c|}{ Kejadian ISPA } & & & \multirow{3}{*}{ p } & \multirow{3}{*}{ Cc } \\
\hline & \multicolumn{2}{|c|}{ ISPA } & \multicolumn{2}{|c|}{$\begin{array}{l}\text { Tidak } \\
\text { ISPA }\end{array}$} & \multicolumn{2}{|c|}{ Jumlah } & & \\
\hline & $f$ & $\%$ & $f$ & $\%$ & $f$ & $\%$ & & \\
\hline $\begin{array}{l}\text { Memenuhi } \\
\text { Syarat }\end{array}$ & 23 & 48.9 & 24 & 51.1 & 47 & 100 & .00 & 0.359 \\
\hline $\begin{array}{l}\text { Tidak } \\
\text { Memenuhi } \\
\text { syarat }\end{array}$ & 50 & 84.7 & 9 & 15.3 & 59 & 100 & & \\
\hline Jumlah & 73 & 68.87 & 33 & 31.13 & 106 & 100 & & \\
\hline
\end{tabular}

2. Hubungan Pencahayaan Alami Rumah dengan Kejadian ISPA Pada Balita

Berdasarkan tabel 4 dapat diketahui bahwa persentase balita yang mengalami ISPA lebih tinggi pada rumah yang pencahayaan alami tidak memenuhi syarat $(77.5 \%)$ dibandingkan yang memenuhi syarat (42.5\%). Dari hasil chi square didapatkan nilai $p$ sebesar $0.001 \quad(p<0.05)$, yang berarti terdapat perbedaan kejadian ISPA pada balita berdasarkan pencahayaan alami rumah yang memenuhi syarat dan tidak memenuhi syarat di wilayah kerja Puskesmas Lubuk Buaya Kota Padang. Dan berdasarkan nilai Coefficient of contingency (Cc) terdapat hubungan yang lemah antara kejadian ISPA dengan pencahayaan alami rumah pada balita di wilayah kerja Puskesmas Lubuk Buaya kota Padang dengan nilai $\mathrm{Cc}=0.311$
Tabel 4. Hubungan Pencahayaan Alami Rumah dengan Kejadian ISPA Pada Balita di Wilayah Kerja

Puskesmas Lubuk Buaya Kota Padang Tahun 2013

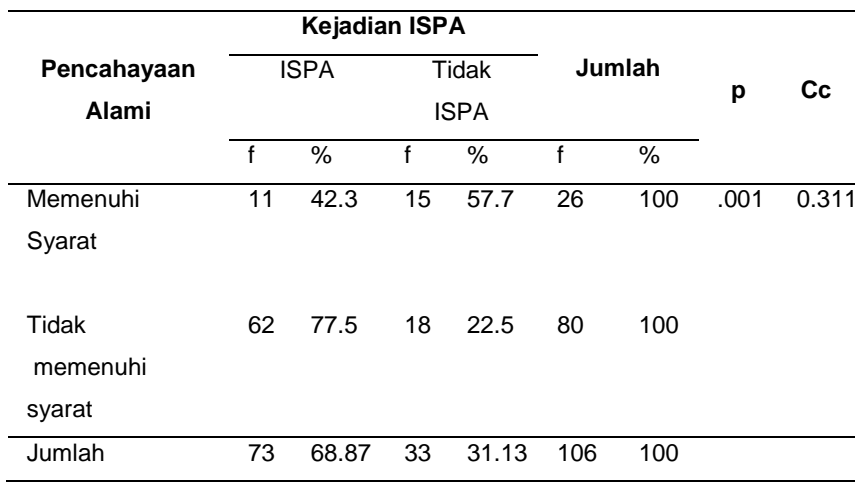

3. Hubungan Kelembaban Rumah dengan Kejadian ISPA Pada Balita

Berdasarkan tabel 5 dapat diketahui bahwa persentase balita yang mengalami ISPA lebih tinggi pada rumah yang kelembabannya memenuhi syarat (70.5\%) dibandingkan yang tidak memenuhi syarat (64.3\%). Dari hasil uji chi square didapatkan nilai $p$ sebesar 0.542 ( $p>0.05)$, yang berarti tidak terdapat perbedaan kejadian ISPA pada balita berdasarkan kelembaban rumah yang memenuhi syarat dan tidak memenuhi syarat di wilayah kerja Puskesmas Lubuk Buaya Kota Padang. Dan berdasarkan nilai Coefficient of contingency $(\mathrm{Cc})$ hubungan antara kejadian ISPA dengan kelembaban rumah pada balita di wilayah kerja Puskesmas Lubuk Buaya kota Padang dapat diabaikan dengan nilai $\mathrm{Cc}=0.059$.

Tabel 5. Hubungan Kelembaban Rumah dengan Kejadian ISPA Pada Balita di Wilayah Kerja Puskesmas Lubuk Buaya Kota Padang Tahun 2013

\begin{tabular}{|c|c|c|c|c|c|c|c|c|}
\hline \multirow{3}{*}{$\begin{array}{c}\text { Kelembaban } \\
\text { Rumah }\end{array}$} & \multicolumn{4}{|c|}{ Kejadian ISPA } & & & \multirow{3}{*}{$\mathbf{p}$} & \multirow{3}{*}{ Cc } \\
\hline & \multicolumn{2}{|c|}{ ISPA } & \multicolumn{2}{|c|}{$\begin{array}{l}\text { Tidak } \\
\text { ISPA }\end{array}$} & \multicolumn{2}{|c|}{ Jumlah } & & \\
\hline & $f$ & $\%$ & $f$ & $\%$ & $f$ & $\%$ & & \\
\hline $\begin{array}{l}\text { Memenuhi } \\
\text { Syarat } \\
(40 \%-70 \%)\end{array}$ & 55 & 70.5 & 23 & 29.5 & 78 & 100 & 0.542 & 0.059 \\
\hline $\begin{array}{l}\text { Tidak } \\
\text { memenuhi } \\
\text { syarat } \\
(<40 \% \text { atau } \\
>70 \%)\end{array}$ & 18 & 64.3 & 10 & 35.7 & 28 & 100 & & \\
\hline Jumlah & 73 & 68,87 & 33 & 31.13 & 106 & 100 & & \\
\hline
\end{tabular}


4. Hubungan Kepadatan Hunian Rumah dengan Kejadian ISPA Pada Balita

Berdasarkan tabel 6 dapat diketahui bahwa persentase balita yang mengalami ISPA lebih tinggi pada rumah yang padat (86.2\%) dibandingkan yang tidak padat (47.9\%). Dari hasil uji chi square didapatkan nilai $p$ sebesar $0.000(p<0.05)$, yang berarti terdapat perbedaan kejadian ISPA pada balita berdasarkan kepadatan hunian rumah yang padat dan tidak padat di wilayah kerja Puskesmas Lubuk Buaya Kota Padang. Dan berdasarkan nilai Coefficient of contingency (Cc) terdapat hubungan yang lemah antara kejadian ISPA dengan kepadatan hunian rumah pada balita di wilayah kerja Puskesmas Lubuk Buaya kota Padang dengan nilai $\mathrm{Cc}=0.381$.

Tabel 6. Hubungan Kepadatan Hunian Rumah dengan Kejadian ISPA Pada Balita di Wilayah Kerja Puskesmas Lubuk Buaya Kota Padang Tahun 2013

\begin{tabular}{|c|c|c|c|c|c|c|c|c|}
\hline \multirow{3}{*}{$\begin{array}{c}\text { Kepadatan } \\
\text { Hunian }\end{array}$} & \multicolumn{4}{|c|}{ Kejadian ISPA } & \multirow{2}{*}{\multicolumn{2}{|c|}{ Jumlah }} & \multirow{3}{*}{$\begin{array}{c}\text { P } \\
\text { Val } \\
\text { ue }\end{array}$} & \multirow{3}{*}{$\mathrm{Cc}$} \\
\hline & \multicolumn{2}{|c|}{ ISPA } & \multicolumn{2}{|c|}{ Tidak ISPA } & & & & \\
\hline & $f$ & $\%$ & $f$ & $\%$ & $f$ & $\%$ & & \\
\hline \multirow[t]{2}{*}{ Padat } & 50 & 86.2 & 8 & 13.8 & 58 & 100 & .000 & 0.3 \\
\hline & & & & & & & & 81 \\
\hline Tidak & 23 & 47.9 & 25 & 52.1 & 48 & 100 & & \\
\hline \multicolumn{9}{|l|}{ Padat } \\
\hline Jumlah & 73 & 68.87 & 33 & 31.13 & 106 & 100 & & \\
\hline
\end{tabular}

5. Hubungan Kebiasaan Merokok dengan Kejadian ISPA Pada Balita

Berdasarkan tabel 7 dapat diketahui bahwa persentase balita yang mengalami ISPA lebih tinggi pada rumah yang anggota keluarganya merokok didalam rumah (80.3\%) dibandingkan yang tidak merokok didalam rumah (50\%). Dari uji chi square didapatkan nilai $p$ sebesar $0.002(p<0.05)$, yang berarti terdapat perbedaan kejadian ISPA pada balita berdasarkan kebiasaan merokok anggota keluarga didalam rumah dan diluar rumah di wilayah kerja Puskesmas Lubuk Buaya Kota Padang. Dan berdasarkan nilai Coefficient of contingency (Cc) terdapat hubungan yang lemah antara kejadian ISPA dengan kebiasaan merokok anggota keluarga didalam rumah pada balita di wilayah kerja Puskesmas Lubuk Buaya kota Padang dengan nilai $\mathrm{Cc}=0.302$.
Tabel 7. Hubungan Kebiasaan Merokok dengan Kejadian ISPA Pada Balita di Wilayah Kerja Puskesmas Lubuk Buaya Kota Padang Tahun 2013

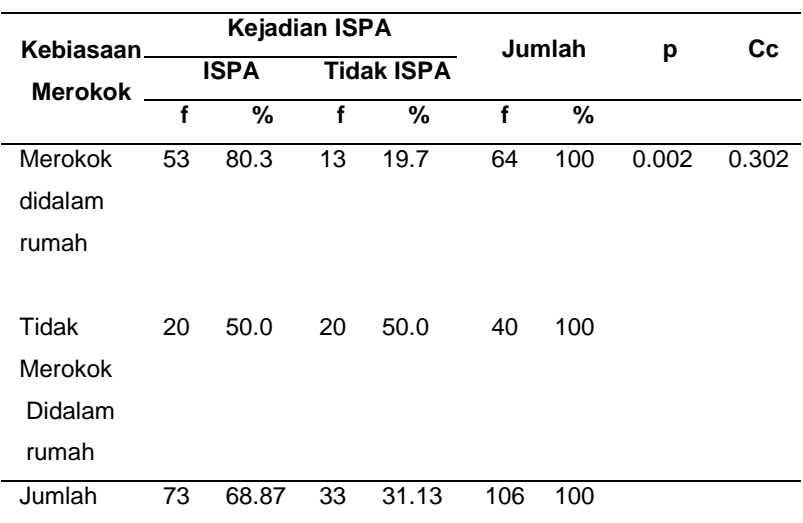

6. Hubungan Kebiasaan Buka Jendela dengan Kejadian ISPA Pada Balita

Berdasarkan tabel 8 dapat diketahui bahwa persentase balita yang mengalami ISPA lebih tinggi pada rumah yang kebiasaan buka jendela rumahnya tidak baik (86.2\%) dibandingkan dengan kebiasaan buka jendela rumah baik (57.1\%). Dari uji chi square didapatkan nilai $p$ sebesar $0.001(p<0.05)$, yang berarti terdapat perbedaan kejadian ISPA pada balita berdasarkan kebiasaan buka jendela yang baik dan tidak baik di wilayah kerja Puskesmas Lubuk Buaya Kota Padang. Dan berdasarkan nilai Coefficient of contingency (Cc) terdapat hubungan yang lemah antara kejadian ISPA dengan kebiasaan buka jendela rumah pada balita di wilayah kerja Puskesmas Lubuk Buaya kota Padang dengan nilai $\mathrm{Cc}=0.333$.

Tabel 8. Hubungan Kebiasaan Buka Jendela dengan Kejadian ISPA Pada Balita di Wilayah Kerja Puskesmas Lubuk Buaya Kota Padang Tahun 2013

\begin{tabular}{|c|c|c|c|c|c|c|c|c|}
\hline \multirow{3}{*}{$\begin{array}{c}\text { Kebiasaan } \\
\text { Buka } \\
\text { Jendela }\end{array}$} & \multicolumn{4}{|c|}{ Kejadian ISPA } & \multirow{2}{*}{\multicolumn{2}{|c|}{ Jumlah }} & \multirow{3}{*}{ p } & \multirow{3}{*}{ Cc } \\
\hline & \multicolumn{2}{|r|}{ ISPA } & \multicolumn{2}{|c|}{ Tidak ISPA } & & & & \\
\hline & $f$ & $\%$ & $f$ & $\%$ & $f$ & $\%$ & & \\
\hline Baik & 40 & 57.1 & 30 & 42.9 & 70 & 100 & 0.001 & 0.333 \\
\hline Tidak & 33 & 91.7 & 3 & 8.3 & 36 & 100 & & \\
\hline \multicolumn{9}{|l|}{ Baik } \\
\hline Jumlah & 77 & 68.87 & 33 & 31.13 & 106 & 100 & & \\
\hline
\end{tabular}

7. Hubungan Penggunaan Bahan Bakar Rumah Tangga dengan Kejadian ISPA Pada Balita 
Berdasarkan tabel 9 dapat diketahui bahwa persentase rumah yang menggunakan bahan bakar tradisional (93.3\%) mengalami ISPA lebih tinggi daripada rumah yang menggunakan bahan bakar modern (64.8\%). Dari uji chi square didapatkan nilai $\mathrm{p}$ sebesar $0.027 \quad(p<0.05)$, yang berarti terdapat perbedaan kejadian ISPA pada balita berdasarkan pengunaan bahan bakar rumah tangga yang tradisional dan modern di wilayah kerja Puskesmas Lubuk Buaya Kota Padang. Dan berdasarkan nilai coefficient of contingency (Cc) terdapat hubungan erat antara kejadian ISPA dengan penggunaan bahan bakar rumah tangga pada balita di wilayah kerja Puskesmas Lubuk Buaya kota Padang dengan nilai $\mathrm{Cc}=0.210$.

Tabel 9. Hubungan Penggunaan Bahan Bakar Rumah Tangga dengan Kejadian ISPA Pada Balita di Wilayah Kerja Puskesmas Lubuk Buaya Kota Padang Tahun 2013

\begin{tabular}{|c|c|c|c|c|c|c|c|c|}
\hline \multirow{3}{*}{$\begin{array}{c}\text { Penggunaan } \\
\text { Bahan Bakar } \\
\text { Rumah } \\
\text { Tangga }\end{array}$} & \multicolumn{4}{|c|}{ Kejadian ISPA } & \multirow{2}{*}{\multicolumn{2}{|c|}{ Jumlah }} & \multirow{3}{*}{ p } & \multirow{3}{*}{ Cc } \\
\hline & \multicolumn{2}{|c|}{ ISPA } & \multicolumn{2}{|c|}{$\overline{\text { Tidak ISPA }}$} & & & & \\
\hline & $f$ & $\%$ & $f$ & $\%$ & $f$ & $\%$ & & \\
\hline \multirow[t]{2}{*}{ Tradisional } & 14 & 93.3 & 1 & 6.7 & 15 & 100 & 0.027 & $\overline{0.210}$ \\
\hline & & 64.8 & & & & & & \\
\hline Modern & 59 & & 32 & 35.2 & 91 & 100 & & \\
\hline Jumlah & 73 & 68.87 & 33 & 31.13 & 106 & 100 & & \\
\hline
\end{tabular}

\section{PEMBAHASAN}

\section{Kejadian ISPA}

ISPA adalah infeksi saluran pernapasan akut yang menyerang salah satu bagian atau lebih dari saluran napas mulai hidung sampai alveoli termasuk adneksanya seperti sinus, rongga telinga tengah, pleura. ${ }^{17}$ Berdasarkan hasil penelitian ditemukan sebanyak $68.87 \%$ balita menderita ISPA. Hasil ini sesuai dengan penelitian Darwel di Puskesmas Air Dingin Padang yang menemukan lebih dari lima puluh persen balita menderita ISPA (64.5\%). ${ }^{15}$

Infeksi saluran pernapasan akut merupakan kasus yang tinggi pada balita dan anak. Penyakit yang diderita oleh anak dibawah 5 tahun, lima puluh persen diantaranya adalah infeksi saluran pernapasan akut. ${ }^{4}$ Infeksi saluran pernapasan akut pada balita ini dipengaruhi oleh berbagai hal seperti faktor lingkungan, faktor individu anak dan faktor perilaku penduduk.

\section{Hubungan Ventilasi Rumah Dengan Kejadian ISPA Pada Balita}

Dari hasil analisis statistik hubungan antara ventilasi rumah dengan kejadian ISPA pada balita di wilayah kerja Puskesmas Lubuk Buaya didapatkan nilai $\mathrm{p}<0.05$ (0.000) dan nilai $\mathrm{Cc}=0.359$. Hal ini berarti terdapat hubungan yang lemah antara ventilasi rumah dengan kejadian ISPA pada balita. Hasil ini sesuai dengan penelitian yang dilakukan oleh Oktaviani di Desa Cepogo, Kabupaten Boyolali dan penelitian oleh Yusup dan Sulistyorini di Kelurahan Penjaringan Sari Kecamatan Rungkut Kota Surabaya. ${ }^{13,14}$ Namun tidak sesuai dengan penelitian Sinaga di kelurahan Warakas Jakarta Utara, dimana didapatkan rumah dengan ventilasi memenuhi syarat lebih banyak menderita ISPA $(75,2 \%)$ dibandingkan rumah dengan ventilasi yang tidak memenuhi syarat $(66.7 \%) .{ }^{18}$

Ventilasi adalah saluran udara untuk proses pergantian udara segar ke dalam dan mengeluarkan udara kotor dari suatu ruangan tertutup. Dengan adanya ventilasi yang baik maka udara segar dapat dengan mudah masuk ke dalam rumah. Menurut Notoatmodjo, rumah yang ventilasinya tidak memenuhi syarat kesehatan akan mempengaruhi kesehatan penghuni rumah. ${ }^{8}$ Hal ini disebabkan karena proses pertukaran aliran udara dari luar ke dalam rumah tidak lancar sehingga bakteri penyebab ISPA yang ada di rumah tidak dapat keluar. Teori Notoatmodjo ini sesuai dengan hasil penelitian dimana kejadian ISPA lebih tinggi terjadi pada rumah dengan ventilasi yang tidak memenuhi syarat kesehatan (84.7\%) dibandingkan rumah dengan ventilasi yang memenuhi syarat kesehatan (48.9\%).

\section{Hubungan Pencahayaan Alami Dengan Kejadian ISPA Pada Balita}

Dari hasil analisis statistik hubungan antara pencahayaan alami rumah dengan kejadian ISPA pada balita di wilayah kerja Puskesmas Lubuk Buaya didapatkan nilai $\mathrm{p}<0.05$ (0.001) dan nilai $\mathrm{C} c=0.311$. Hal ini berarti terdapat hubungan yang lemah antara pencahayaan alami rumah dengan kejadian ISPA pada balita. Hasil ini sesuai dengan penelitian yang 
dilakukan oleh Suryani di Puskesmas Gemarang Kabupaten Ngawi dan Wattimena di Curug Kabupaten Tanggerang. ${ }^{19,20}$ Namun tidak sesuai dengan penelitian Sinaga di kelurahan Warakas Jakarta Utara, dimana didapatkan hasil yang hampir sama antara rumah dengan pencahayaan alami yang memenuhi syarat $(74,2 \%)$ dan yang tidak memenuhi syarat $(74.8 \%)$ dengan nilai $p>0.05$ (1.000) yang berarti tidak ada hubungan antara pencahayaan alami rumah dengan kejadian ISPA pada balita. ${ }^{18}$

Pencahayaan alami adalah penerangan rumah secara alami oleh sinar matahari melalui jendela, lubang angin dan pintu dari arah timur di pagi hari dan barat di sore hari. Pencahayaan alami sangat penting dalam menerangi rumah untuk mengurangi kelembaban. Rumah yang sehat harus mempunyai jalan masuk cahaya matahari dari arah barat dan timur sekurang-kurangnya 15\%-20\% dari luas lantai yang terdapat didalam rumah. ${ }^{21}$ Selain berguna untuk pencahayaan, sinar ini juga mengurangi kelembaban ruangan, mengusir nyamuk atau serangga lainnya dan membunuh kuman penyebab penyakit tertentu.

\section{Hubungan Kelembaban Rumah Dengan Kejadian ISPA Pada Balita}

Dari hasil analisis statistik hubungan antara kelembaban rumah dengan kejadian ISPA pada balita di wilayah kerja Puskesmas Lubuk Buaya didapatkan nilai $p>0.05$ (0.542) dan nilai $\mathrm{Cc}=0.059$. Hal ini berarti tidak terdapat hubungan antara kelembaban rumah dengan kejadian ISPA pada balita. Hasil ini sesuai dengan penelitian yang dilakukan oleh Sinaga di kelurahan Warakas Jakarta Utara, Yusup dan Sulistyorini di Kelurahan Penjaringan Sari Kecamatan Rungkut Kota Surabaya serta Oktaviani di desa Cepogo Kabupaten Boyolali. ${ }^{13,18,22}$ Namun hasil ini tidak sesuai dengan penelitian Suryani di Puskesmas Gemarang Kabupaten Ngawi. ${ }^{19}$

Kelembaban adalah presentasi jumlah air di udara atau uap air dalam udara. Kelembaban yang tinggi dapat menyebabkan membrane mukosa hidung menjadi kering sehingga kurang efektif dalam menghadang mikroorganisme sehingga lebih mudah terkena infeksi saluran pernapasan. Kelembaban rumah dipengaruhi oleh banyak faktor seperti pencahayaan baik alami maupun buatan, ventilasi, suhu rumah dan dinding rumah.

\section{Hubungan Kepadatan Hunian Rumah Dengan kejadian ISPA Pada Balita}

Dari hasil analisis statistik hubungan antara kepadatan hunian rumah rumah dengan kejadian ISPA pada balita di wilayah kerja Puskesmas Lubuk Buaya didapatkan nilai $\mathrm{p}<0.05(0.000)$ dan nilai $\mathrm{Cc}=$ 0.381 . Hal ini berarti terdapat hubungan yang lemah antara kepadatan hunian rumah dengan kejadian ISPA pada balita. Hasil ini sesuai dengan penelitian yang dilakukan oleh Oktaviani dkk di Kelurahan Cambai Kota Prabumulih, Suryani di Puskesmas Gemarang Kabupaten Ngawi serta Yusup dan Sulistyorini di Kelurahan Penjaringan Sari Kecamatan Rungkut Kota Surabaya. ${ }^{13,14,22}$

\section{Hubungan Kebiasaaan Merokok Anggota Keluarga Dengan Kejadian ISPA Pada Balita}

Dari hasil analisis statistik hubungan antara kebiasaan merokok anggota keluarga didalam rumah dengan kejadian ISPA pada balita di wilayah kerja Puskesmas Lubuk Buaya didapatkan nilai $\mathrm{p}<0.05$ (0.002) dan nilai $\mathrm{Cc}=0.302$. Hal ini berarti terdapat hubungan yang lemah antara kebiasaan merokok anggota keluarga diidalam rumah dengan kejadian ISPA pada balita. Hasil ini sesuai dengan penelitian yang dilakukan oleh Darwel di Puskesmas Aia Dingin Kota Padang serta Trisnawati dan Juwarrni di Puskesmas Rembang Kabupaten Purbalingga. ${ }^{15,23}$ Namun tidak sesuai dengan penelitian yang dilakukan Sinaga di kelurahan Warakas Jakarta Utara. ${ }^{18}$

Asap rokok dari penghuni rumah yang tinggal satu atap dengan balita merupakan bahan pencemaran dalam ruang tempat tinggal yang serius serta akan menambah risiko kesakitan pada balita. Paparan yang terus-menerus akan menimbulkan gangguan pernapasan terutama memperberat timbulnya ISPA. Semakin banyak rokok yang dihisap oleh keluarga maka semakin besar memberikan risiko terhadap kejadian ISPA. ${ }^{7}$

\section{Hubungan Kebiasaan Buka Jendela Dengan Kejadian ISPA Pada Balita}


Dari hasil analisis statistik hubungan antara kebiasaan buka jendela rumah dengan kejadian ISPA pada balita di wilayah kerja Puskesmas Lubuk Buaya didapatkan nilai $\mathrm{p}<0.05(0.001)$ dan nilai $\mathrm{Cc}=0.333$. $\mathrm{Hal}$ ini berarti terdapat hubungan yang lemah antara kebiasaan buka jendela rumah dengan kejadian ISPA pada balita. Hasil ini tidak sesuai dengan penelitian yang dilakukan oleh Safitri dan Keman di Desa Labuhan Kecamatan Labuhan Badas Kabupaten Sumbawa. $^{24}$ Mereka mendapatkan tidak ada hubungan antara kebiasaan membuka jendela ruang keluarga maupun ruang tidur dengan kejadian ISPA pada balita karena kebiasaan untuk membuka jendelanya sangat baik.

Jendela rumah berfungsi sebagai ventilasi, merupakan tempat keluar masuknya udara. Selain itu jendela juga berfungsi untuk tempat masuknya cahaya matahari. Ventilasi sangat mempengaruhi kualitas udara dalam rumah. Namun hal ini tidak akan berfungsi dengan baik apabila ventilasi tersebut berupa jendela namun tidak pernah dibuka. Hal ini sejalan dengan hasil penelitian yang didapatkan bahwa kejadian ISPA pada balita lebih tinggi pada rumah dengan jendela yang jarang dan tidak pernah dibuka (91.7\%) dibandingkan dengan jendela yang selalu dibuka (57.1\%).

\section{Hubungan Antara Pengunaan Bahan Bakar Rumah Tangga Dengan Kejadian ISPA Pada Balita}

Dari hasil analisis statistik untuk hubungan antara penggunaan bahan bakar rumah tangga dengan kejadian ISPA pada balita di wilayah kerja Puskesmas Lubuk Buaya didapatkan nilai $\mathrm{p}<0.05$ (0.027) dan nilai $\mathrm{Cc}=0.210$. Hal ini berarti terdapat hubungan yang lemah antara penggunaan bahan bakar rumah tangga berupa bahan bakar tradisional yakni kayu bakar dengan kejadian ISPA pada balita. Hasil ini sesuai dengan penelitian yang dilakukan oleh Wattimena di Curug Kabupaten Tanggerang namun tidak sesuai dengan penelitian Darwel di Aia Dingin Padang dan Sinaga di kelurahan Warakas Jakarta Utara. $^{15,18,20}$

Bahan bakar rumah tangga yang berasal dari kayu / tradisonal akan menghasilkan asap yang lebih banyak daripada bahan bakar modern seperti kompor minyak ataupun kompor gas. Hal ini akan mempengaruhi kondisi udara dalam rumah. Asap yang berasal dari hasil pembakaran kayu mengandung banyak karbon monoksida. Bayi dan anak yang sering menghisap asap tersebut di dalam rumah lebih mudah terserang ISPA. ${ }^{7}$

\section{KESIMPULAN}

Berdasarkan hasil dan pembahasan dalam penelitian ini, maka dapat diambil kesimpulan bahwa: Ada hubungan yang lemah antara ventilasi rumah dengan kejadian ISPA pada balita di wilayah kerja Puskesmas Lubuk Buaya Kota Padang tahun 2013; Ada hubungan yang lemah antara pencahayaan alami rumah dengan kejadian ISPA pada balita di wilayah kerja Puskesmas Lubuk Buaya Kota Padang tahun 2013; Ada hubungan yang lemah antara kepadatana hunian rumah dengan kejadian ISPA pada balita di wilayah kerja Puskesmas Lubuk Buaya Kota Padang tahun 2013; Tidak ada hubungan antara kelembaban rumah dengan kejadian ISPA pada balita di wilayah kerja Puskesmas Lubuk Buaya Kota Padang tahun 2013; Ada hubungan yang lemah antara kebiasaan merokok anggota keluarga didalam rumah dengan kejadian ISPA pada balita di wilayah kerja Puskesmas Lubuk Buaya Kota Padang tahun 2013; Ada hubungan yang lemah antara kebiasaan buka jendela rumah dengan kejadian ISPA pada balita di wilayah kerja Puskesmas Lubuk Buaya Kota Padang tahun 2013; Ada hubungan yang lemah antara penggunaan bahan bakar rumah tangga dengan kejadian ISPA pada balita di wilayah kerja Puskesmas Lubuk Buaya Kota Padang 2013.

\section{UCAPAN TERIMA KASIH}

Terima kasih penulis ucapkan kepada dr. Edison, MPH dan Dra. Julizar Nazar, M.Kes, Apt yang telah memberikan bimbingan dan arahan dalam penulisan hasil penelitian ini. Kepada pimpinan dan staf Puskesmas Lubuk Buaya dan puskesmas pembantu di wilayah kerja Puskesmas Lubuk Buaya yang telah membantu pelaksanaan penelitian ini.

\section{DAFTAR PUSTAKA}

1. Kementerian Kesehatan RI. Buletin jendela data 
dan informasi kesehatan: situasi ISPA di Indonesia. Jakarta: Kementerian Kesehatan RI; 2010.

2. World Health Report (WHO). Changing history. Geneva: World Health Organization; 2004.

3. Departemen Kesehatan Republik Indonesia. Profil kesehatan Republik Indonesia 2010. Jakarta: Departemen Kesehatan Republik Indonesia; 2011.

4. Wantania JM, Naning $R$, Wahani A. Infeksi respiratori akut. Dalam: Buku Ajar Respirologi Anak. Jakarta: Badan Penerbit IDAI; 2010. hlm. 268-75.

5. Riskesdas. Riset kesehatan dasar 2007. Jakarta: Badan Penelitian dan Pengembangan Kesehatan $\mathrm{RI} ; 2008$.

6. Prabu. Faktor Resiko ISPA pada Balita; 2009 (diunduh 25 Mei 2013). Tersedia dari: URL: HYPERLINK http://www.putraprabu.wordpress. com

7. Departemen Kesehatan Republik Indonesia. Pemberantasan penyakit ISPA untuk penanggulangan pneumonia balita. Jakarta: Departemen Kesehatan Republik Indonesia; 2002.

8. Notoatmodjo S. IImu kesehatan masyarakat (Prinsip-prinsip dasar). Jakarta: Rineka Cipta; 2003.

9. Rudan I, Pinto CB, Biloglav Z, Mulholland K, Campbell H. Epidemiology and etiology of childhood pneumonia; 2008 (diunduh 25 Mei 2013). Tersedia dari: URL: HYPERLINK http://www.who.int/bulletin/volumes/86/5/07048769/en/

10. EPA Development. Fact sheet: respiratory health effects of passive smoking; 2009 (diunduh 25 Mei 2013). Tersedia dari: URL: HYPERLINK http://www.epa.gov/smokefree/pubs/etsfs.html

11. Departemen Kesehatan Republik Indonesia. Perokok pasif mempunyai resiko yang lebih besar; 2009 (diunduh 25 Mei 2013). Tersedia dari: URL: HYPERLINK http://www.depkes.go.id

12. Nindya ST, Sulistyorini L. Hubungan sanitasi rumah dengan kejadian ISPA pada anak balita. Jurnal Kesehatan Lingkungan, Juli 2005;2(1)

13. Oktaviani, VA. Hubungan antara sanitasi fisik rumah dengan kejadian ISPA pada balita di desa
Cepogo Kecamatan Cepogo Kabupaten Boyolali. Surakarta: FKM Universitas Muhammadiyah Surakarta. 2010.

14. Oktaviani D, Fajar, Purba IG. Hubungan kondisi fisik rumah dan perilaku keluarga terhadap kejadian ISPA pada anak balita di kelurahan Cambai Kota Prambulih Tahun 2010. Jurnal Pembangunan Manusia, 2010;4(12).

15. Darwel. Hubungan kualitas rumah dan aktifitas keluarga dengan kejadian ISPA balita di wilayah kerja Puskesmas Air Dingin Kota Padang. Padang: FK Universitas Andalas; 2007.

16. Dinas Kesehatan Kota Padang. Laporan bulanan program P2 ISPA kota Padang. Padang: Dinas Kesehatan Kota Padang; 2012.

17. Dirjen P2PL. Pedoman pengendalian infeksi saluran pernapasan akut. Jakarta: Kementrian Kesehatan Republik Indonesia; 2012.

18. SinagaER K. Kualitas lingkungan fisik rumah dengan kejadian infeksi saluran pernapasan akut (ISPA) pada balita di wilayah kerja Puskesmas Kelurahan Warakas Kecamatan Tanjung Priok Jakarta Utara Tahun 2011. Jakarta: FKM Universitas Indonesia; 2012.

19. Suryani, Putri. Hubungan kondisi lingkungan fisik rumah dengan kejadian ISPA pada balita di wilayah kerja Puskesmas Gemaran Kabupaten Ngawi. 2010 (diunduh 22 Mei 2013). Tersedia dari: URL: HYPERLINK http://eprints.undip.ac.id/ 32393/1/3836.pdf.

20. Wattimena, Calvin. Faktor lingkungan rumah yang mempengaruhi hubungan kadar PM10 dengan kejadian ISPA pada balita di wilayah Puskesmas Curug Kabupaten Tanggerang Tahun 2004 (tesis). Jakarta: Program Pasca Sarjana FKM Universitas Indonesia; 2004.

21. Menteri Kesehatan Republik Indonesia. Peraturan Menteri Kesehatan Republik Indonesia Nomor 1077/Menkes/Per/V/2011 tentang Pedoman Penyehatan Udara Dalam Ruang Rumah. Jakarata: Kementerian Kesehatan Republik Imdonesia; 2011.

22. Yusup NA, Sulistyorini L. Hubungan sanitasi rumah secara fisik dengan kejadian ISPA pada balita. Jurnal Kesehatan Lingkungan, Januari 2005;1(2). 
23. Trisnawati $Y$, Juwarni. Hubungan perilaku merokok orang tua dengan kejadian ISPA pada balita di wilayah kerja Puskesmas Rembang Kabupaten Purbalingga 2012. Purwokerto: Akademi Kebidanan YLPP; 2012.
24. Safitri $A D$, Keman S. Hubungan tingkat kesehatan rumah dengan kejadian ISPA pada anak balita di Desa Labuhan Kecamatan Labuhan Badas Kabupaten Sumbawa. Jurnal Kesehatan Lingkungan, Januari 2007; 3(2):139-50. 